\title{
E-activities of a Quality Control course, and their effect on the motivation, knowledge and performance of students at the Costa Rican Distance State University
}

\author{
Carmen Andrés Jiménez \\ National Distance State University, PO Box 474-2050 Mercedes de Montes de Oca, San José-Costa Rica; candres@uned.ac.cr
}

Received 20-IV-2012 Corrected 14-VI-2012 Accepted 13-VII-2012

\begin{abstract}
Student-centered learning helps students motivate themselves and straighten their ability to learn and solve problems. The fact that the students focus more on a final grade than their learning process does not necessarily help them learn. The purpose of this investigation was to evaluate the e-activities and tests of a Quality Control course taught during the third term of 2011 at the Costa Rican Distance State University (UNED), and to find a relationship between them and the students' motivation, performance and knowledge. A total of 31 students took the course, which was evaluated through summative evaluation, self evaluation, a survey, corroboration of the student's performance and statistical analyses. Participation in the "cafeteria forum" implied better grades in their first and second exam (Spearman 0,78; 0,78). Those who read the rubrics of the investigation project and the case to solve, got better grades (Spearman 0,90; 0,79), but there was no correlation among the participations of the students in the platform and the final grades of the course $(0,26)$. Self evaluation and the survey showed students learned only $54 \%$ and $53 \%$, respectively, of what was expected. A general discomfort and bad performance was found. It is recommended to turn to alternative evaluation, organize themes and materials of the course in a different way, pay more attention to students with greater need, encourage them to participate and to monitor student's performance next time this course is taught.
\end{abstract}

\section{KEY WORDS}

Evaluation, learning process, self evaluation, student-centered, performance, motivation, TIC.

\section{RESUMEN}

El aprendizaje centrado en el estudiante lo ayuda a motivarse y a fortalecer su habilidad para resolver problemas. El hecho de que los estudiantes se enfoquen más en una nota final que en su proceso de aprendizaje no necesariamente implica que aprenderán. El propósito de esta investigación fue evaluar las actividades en línea y los exámenes del curso Control de Calidad, impartido durante el tercer cuatrimestre del 2011, así como encontrar una relación entre estas actividades y el aprendizaje, rendimiento y motivación de los estudiantes.En total 31 estudiantes tomaron el curso, el cual fue evaluado a través de evaluación sumativa, autoevaluación, una encuesta, corroboración del desempeño de los estudiantes y análisis estadístico. La participación en el "foro de cafetería" implicó una mejor nota en el primero y segundo examen (Spearman 0,78; 0,78). Además, las personas que leyeron las rúbricas del proyecto de investigación y el caso a resolver, obtuvieron mejores notas (Spearman 0,$90 ; 0,79$ ), pero no hubo correlación entre las participaciones de los estudiantes en el foro de cafetería y la nota final del curso (Spearman 0,26).La autoevaluación y encuesta mostraron que los estudiantes aprendieron solo un $54 \%$ y $53 \%$ respectivamente de lo que se esperaba. Se notó un descontento general y un bajo rendimiento. Se recomienda utilizar la evaluación alternativa, organizar los temas y materiales del curso de manera diferente, poner más atención a los estudiantes que más lo necesitan, animarlos a participar, y monitorear el rendimiento de los estudiantes la próxima vez que se imparta el curso..

\section{PALABRAS CLAVE}

Evaluación, proceso de aprendizaje, autoevaluación, centrado en el estudiante, rendimiento, motivación.
Online courses have been developed at the National Distance State University of Costa Rica and there has been much training for teachers and students in order to make this work.

The Agroindustry chair offers all its courses on line, some with presential components depending on their level of difficulty. It is the goal of the chair to motivate students to learn and to get a good performance in their courses. In order to achieve this goal, each course is being analyzed through the eyes of the student's motivation, learning process and performance. 
Motivation is an important factor in the learning process; frustration and lack of motivation affect performance. According to Borges, 2005, the consequences of the student's frustration can be dangerous to all the factors that take part in on line education: student, teachers and the University.

So, motivation has become a priority for the chair, since it cannot be acceptable to have students unwilling to fight for the course if the chair can do something about it, whether it implies more phone calls, more e-mails, more interaction, extra exercises or any other help each student might need.

Alorda et al. (2009), comment that the student's motivation works out within the expectation of success the student has and the quality of the course he or she is taking (Alorda et al., 2009). That is why it is necessary to analyze and work on an improvement plan to perk up the excellence of the Quality control course.

But, the way to motivate our students is our concern. We've realized that even when UNED is a distance university, having contact with the students is a must in order to understand their needs, the way they learn, how they visualize TIC and how the chair can help them improve this knowledge. Students are sometimes so lost, they do not pick up the phone and ask. On the other hand, some are also too busy, but when the chair calls them they are grateful and motivated to work.

Thorpe, 2010, affirms that some cognitive strategies have been investigated to give students options according to their different needs. Every student is motivated by different strategies, thus giving them this choice can improve their motivation, and therefore their knowledge and performance.

UNED has its pedagogical model student centered. Some of the reasons to adopt a student centered model are the following: a) strengthens the student's motivation, b) promotes communication among students, c) encourages an active discovery development and the student feels responsible for his or her own learning process. It has also been studied that reducing magisterial classes and encouraging group work challenges help students make decisions and face problems they would face in the real world (Thorpe, 2010).

Self evaluation is a good way to apply the student centered model of UNED and measure the student's learning process. Students gain more independence and self control when supervising their progress (Quesada, 2006). This was done in the Quality Control course and will be applied to the rest of the courses as part of their grade to force students to be more aware of their learning process.
Metacognition is the base to acquire a good self evaluation. Students should own their knowledge instead of just studying for a test, but this is hard to accomplish. Pujola, 2008 , explains that to be able to focus on the knowledge the student is getting, their own learning process must be evaluated and monitored. The student has to do it in an autonomous, responsible and mature way. Besides, the ability to self evaluate their own work, helps students be successful in their learning process.

Boud \& Falchikov (2006), mentioned by Padilla-Carmona et al., 2010, state there are three purposes of evaluation: to certify, to learn and as an impulse to the learning for life (Padilla-Carmona et al., 2010). Taking this into account, implies that evaluation needs to be alternative, not a final grade, but a learning process; in order to improve students' motivation, knowledge and performance.

There are three types of evaluation: diagnostic, formative and summative. Even when performance is important to the Agroindustry chair, in order to have a parameter with which the students can be measured, diagnostic and formative evaluation have to be present in every course, along with activities and practices that motivate the student and develop its learning process.

Regarding formative evaluation, it is a good way to help students improve their learning process, motivation and performance. Feedback needs to be clear, prompt and correct for each problem (Quesada, 2006). On this matter the Agroindustry chair has had good results, but there's always a part of the population that is not interested on this feedback because they're not motivated enough, they have trouble with technology or do not have enough time.

It is also very important to learn from the mistakes the students make during tests and the e-activities. If the test is returned to the student and there's no feedback, the test was not really worth it (Vincenzi \& Angelis, 2008).

It is also a goal of the Chair to help its students learn something they will remember, instead of making them memorize what they're going to forget. According to several investigations, university students tend to focus on their final grade, which implies getting into class, complying with assignments and studying for tests. And this effort does not necessarily contribute to their knowledge, because more importance is given to the final grade than to the learning process (Andrés et al., 2010).

The purpose of this investigation was to evaluate the e-activities and tests of the Quality Control course taught during the third term of 2011 and find a relationship between them and the students' motivation, performance and knowledge. 


\section{METHODOLOGY}

The Quality Control course is taught every third term (once a year) to 30 students. During 2011, 31 students took this course and three evaluation instruments were used, (a case to solve, a forum and an investigation project), which had to be handed in through the virtual platform Moodle. Also, two written exams were evaluated. Students were also allowed to interact and ask questions through the cafeteria forum in the platform.

\section{Students' performance and knowledge}

The students' performance and knowledge was evaluated through two set of tools:

a. Summative evaluation: the students were evaluated through forum, a case to solve, an investigation project and two written exams. The first three instruments had rubrics(appendixes 1,2 and 3).

b. A self evaluation sheet: this was sent to the students through the Moodle platform, to determine how aware the students were about their learning process (Appendix 5).

\section{Students' motivation}

The students' motivation was measured through two different methods:

a. A survey which asked the students' opinion about different aspects related to the course: e-learning, themes of the course, motivation, metacognition, evaluation techniques and given materials (Appendix 4). b. An analysis of the student's participations in the "cafeteria forum", to determine how they perceived the course and the level of satisfaction they achieved.

\section{Statistic analysis}

A Spearman correlation statistical test was applied to find correlations between the following aspects:

a. The motivation of the students, and their performance.

b. The fact that the students entered the platform to check the rubrics and their performance.

c. Students who participated in the cafeteria forum and those who did not and their performance.

\section{RESULTS}

\section{Students' performance and knowledge}

\section{Summative evaluation}

A third of the students obtained a final grade between 71 and 90. The Grades of all the students are shown in Figure 1.

Applying a Spearman correlation trying to relate the final grade with the participations in the Cafeteria forum, a positive relation was found 0,78 (Fig. 2).

The results per evaluation instrument are shown in Figure 3.

Spearman correlation were applied to find out if the fact of reading the rubrics has some effect on the final grade of the students (Case to solve 0,79; Investigation project 0,90 and Forum 0,05 ).

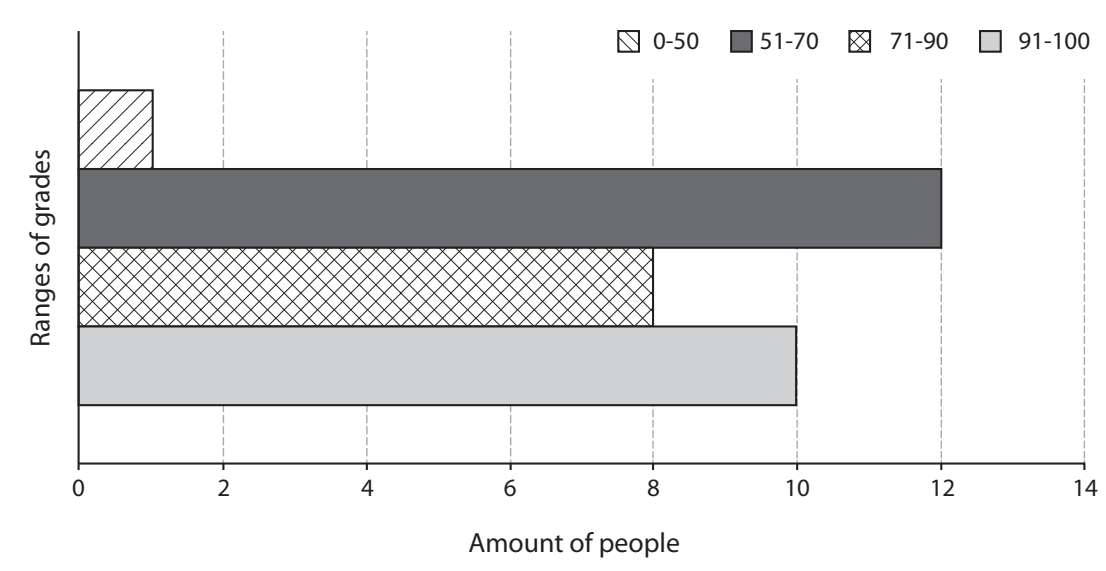

FIG. 1. Ranges of the final grade and amount of people within these ranges (31 students took the Quality Control course during the third term of 2011). 
A Spearman correlation was done among the grades of the tests and the frequency which with the students participated in the Cafeteria forum and the results were the first test 0,78 and the second one 0,78 .

\section{Self-evaluation}

The results obtained from the self evaluation turned out into an average of $54 \%$ of positive answers.

\section{Students' motivation}

\section{Survey results}

The results of the survey were analyzed based on how the students were supposed to respond. The results are shown in Figure 4.

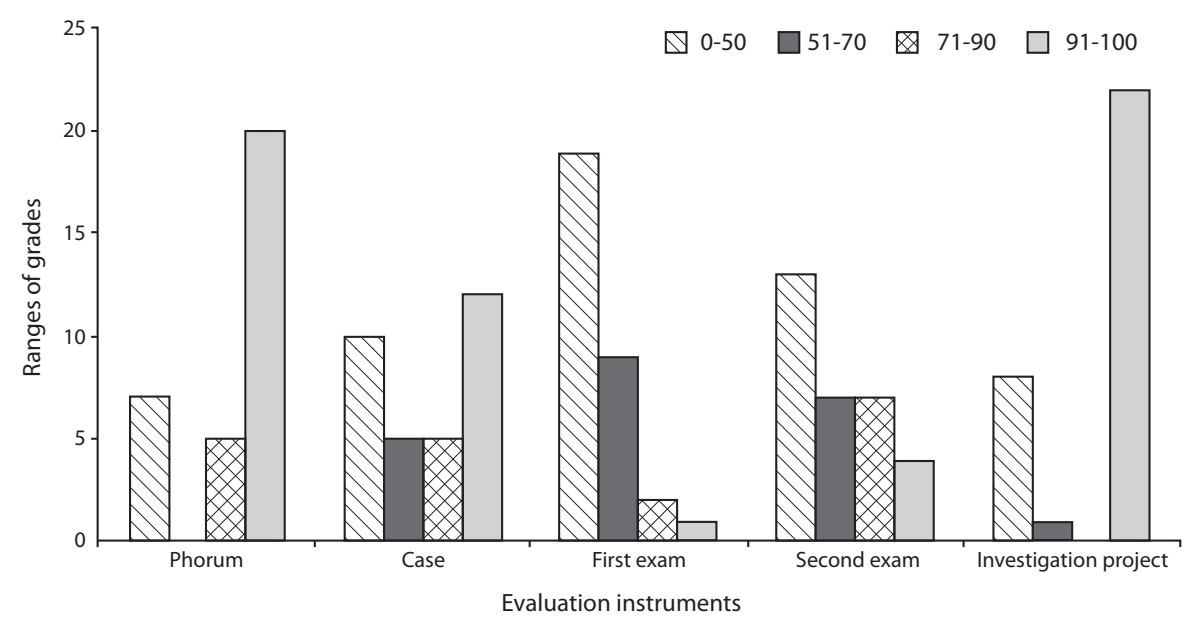

FIG. 2. Performance per evaluation instrument of the 31 students that took the Quality Control course during the third term of 2011.

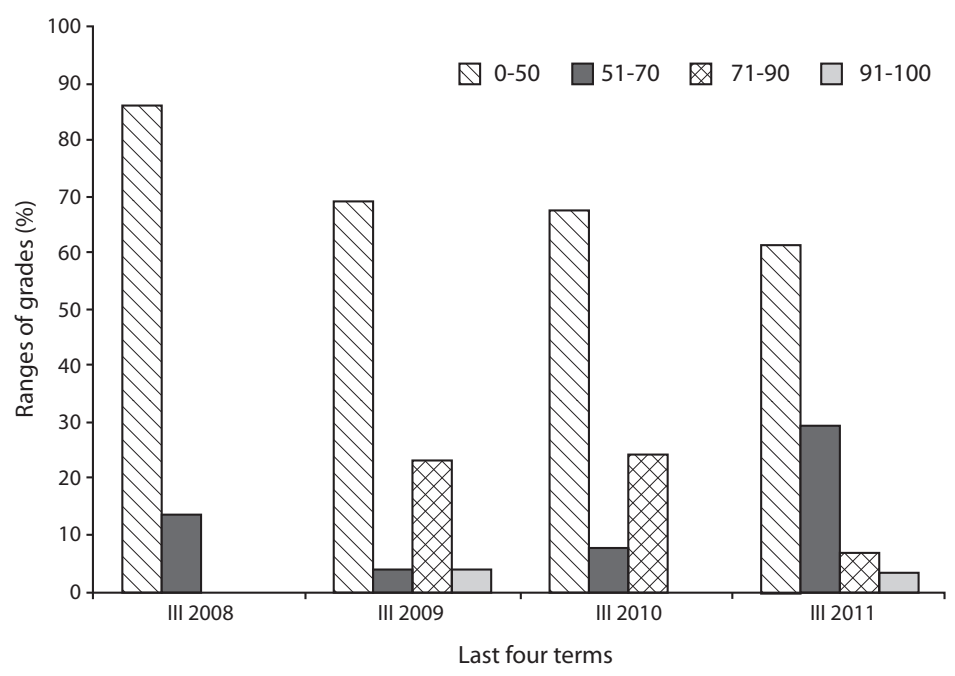

FIG. 3. First exam's performance of the 31 students that took the Quality Control course, during the third term of 2011. 


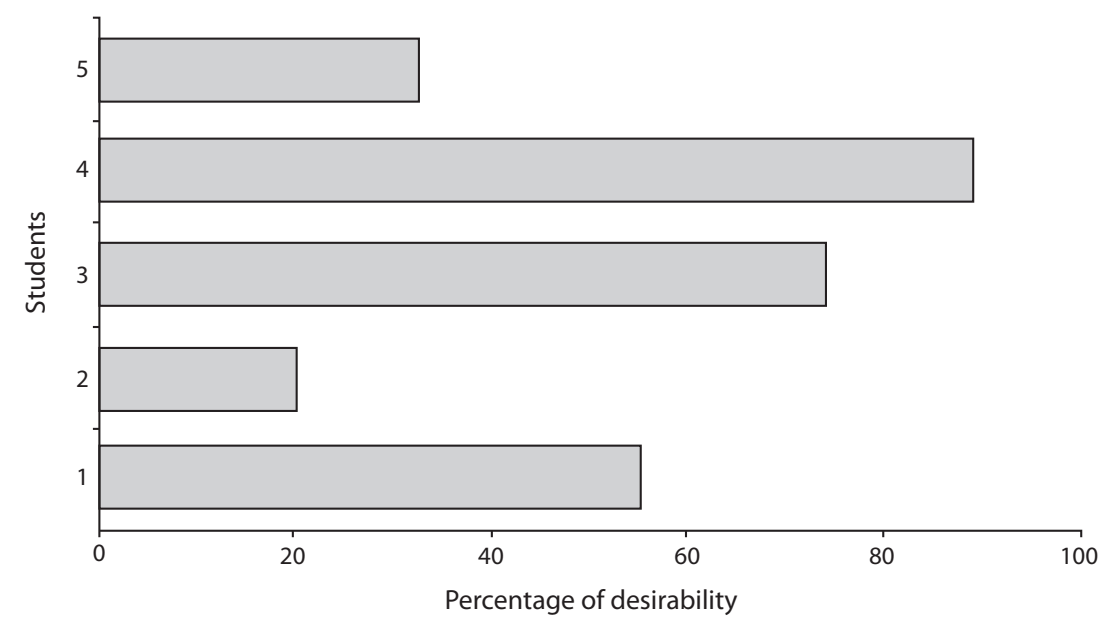

FIG. 4. Responses of the students in the survey related tothe Quality Control course.

\section{Survey, cafeteria forum and self evaluation comments}

The participation of each student in the cafeteria forum, as well as the comments they wrote in the survey and the self evaluation were analyzed. In Figure 5, we can see the general participation of the students in the platform.

A Spearman test was done to find out if these participations are related to the performance of the students. The Spearman correlation coefficient was 0.26 .

The following aspects were taken from the cafeteria forum and the self evaluation sheet handed in by the students. These need to be considered in the following promotions of the course:

a. The course has a high level of statistics. Some students think a statistics course should be taken before Quality Control.

b. The teacher told the students to study from the study guide instead of the book because it was supposed to be clearer and with less topics; but this study guide has a higher level of statistics than the book, thus this was something that really confused the students. Nevertheless, the teacher was very prompt in answering all the e-mails and questions from each student and things were clear as far as the methodology.

c. The text book is not designed to study at home (it's a presential class type). A study guide was written, but it has mistakes that need to be corrected for the next promotions till a new book can be written. d. A video conference was suggested by some students, the ones that live far from San José. This can be considered for the next promotion of the course.

e. Students think it is necessary to have more than one class for the course (the rest is virtual). This will be taken in consideration, specially the video conference suggestion.

f. Students agreed with the idea of handing in their homework through the platform instead of printing it. But in average, only a $50 \%$ of the students used the platform to hand in homework.

g. The investigation project instructions were not as clear as the students needed. Even when this was the homework that had higher grades, the chair needs to pay attention to this observation and do a better job.

h. The exams had a higher level of difficulty than expected.

\section{DISCUSSION}

Student's motivation, knowledge and performance are intertwined according to what is shown in this investigation as we will analyze each part of the results.

The fact some students were more communicative and proactive (reading instructions or rubrics before handing in their papers)made them have better grades, as it's exposed in the results (Figure 1).The only evaluation instrument that did not have a positive correlation among the final grade of the students and the reading of the rubric, 


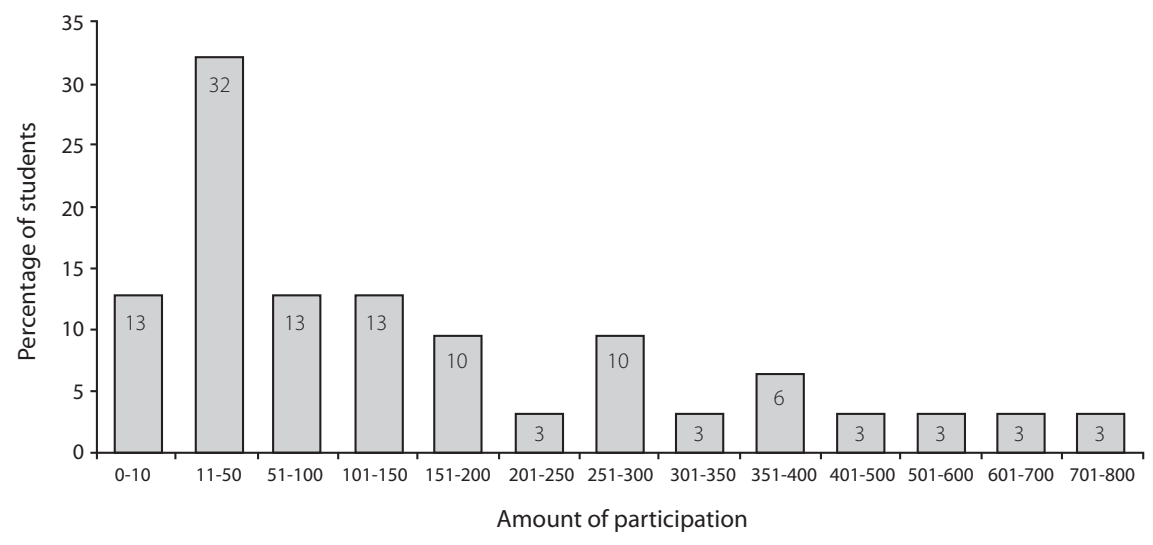

FIG. 5. Amount of participations students had in the platform throughout the Quality Control course in the third term of 2011.

was the forum (Figure 2, Table 1). This might be due to the fact that a forum is a freer activity that can be accomplished through different approaches and so the final grade can be similar.

Not all students can be communicative and proactive by themselves. Teachers need to help them. Thorpe, 2010, says there must be a balance between the student centered model and the teacher centered model. Helping the student understand, motivating him or her to call as much as he or she needs, and having more presence in the virtual platform, is a plus for most students. Some of them do not need this kind of help, because their level of metacognition is high, but every student is different (Thorpe, 2010).

An interesting fact that was obtained from this research was that the first exam was one of the instruments that turned out with lower grades, for three years in a row (Figure 3 ). This course is taught only once a year and coincidentally, since the year 2008 and the promotion for this first test, as an average, has always been between $24 \%$ and $27 \%$, being $0 \%$ in the year 2008 . This reveals more effort has to be put into the teaching and learning for this first test, the chair and teachers as well as the students need to pay more attention to these themes and the strategy, as will be pointed out later, needs to change to achieve better results.

As for the self evaluation exercise, the percentage of positive answers (54\%) means the average learning was half of what was expected from the student. This result, even when it's only a reference due to the low amount of students that did the exercise, implies corrective actions need to be taken such as increasing alternative evaluation through co evaluation, self evaluation, activities that do not imply a grade but that are mandatory, organizing the themes differently to help students have a clearer vision of the course, activities that will help the student learn instead of studying for a test, paying more attention to the students that need it and more feedback so that students can actually learn.

Further on, the survey had similar results than the self evaluation. Only 5 students answered it, the percentage of desirability was $53 \%$. The results are not significant, due to the same reason the self evaluation was not, but only as a reference it is important to motivate students to participate in these kinds of activities, since it's a good tool and feedback to improve the quality of the courses. They did not get a grade for doing this, which might have not been motivating. Suárez \& Fernández point out that the more the student gets involve in the activities of the course, the better its performance and learning strategies will be and therefore it will feel more motivated (Suárez \& Fernández, 2011).

As an analysis of the student's participation in all the activities of the platform, figure 5 shows the behavior students and their teacher had: students participated in the activities in the Moodle platform from 50 to 100 times. The teacher participated 750 times, which shows her constancy and interest in the course throughout the term.

Even when participating in the cafeteria forum improved the final grades of the students as well as their grades in the first and second exam, the participation 
in the platform in general is not directly related to the performance. Ayala-Valenzuela \& Torres-Andrade (2007), found "emotions are the most important aspect to improve the learning process in education", thus, discomfort and poor performance need to be fought through motivation, which generates positive emotions

As we have seen through the results, there was a general discomfort as well as poor performance. Their comments must be taken into account the next time this course is taught.

The results of this investigation showed that the students were not motivated in the course and did not feel a proper guidance was being given to them. It was shown students do not evaluate and monitor their own work and they are not interested in participating in activities that do not have a grade. Moreover, the students who are communicate and participate in the virtual platform are more interested in the activities to get better grades than the ones that did not.

The quality of the Quality control course regarding alternative evaluation, organization of their themes and materials, attention to the students who need it most, give more feedback and encourage students to participate in all activities (and give it a percentage of the grade) needs to be improved in order to have a better promotion in the third term of 2013.

\section{ACKNOWLEDGEMENTS}

I thank all the students of the Quality Control course taught during the third term of 2011, who contributed so gently to this investigation, their effort and support and the difference they made with their enthusiasm. I also thank Sandra Zamora, teacher of the course, for her support and the effort she put into this course.

\section{REFERENCES}

Alorda, B; Álvarez, M.J; Barranco, M; Bota, S; Bonnin, F; Burguera, A; Carrasco, L; Cladera, A; Horrach, G; Guerrero, J; Llabés, M; Martínez, V; Moiá, A; Payeras, M; Picos, R; Ramis, J; Roca, M; Rodríguez, N; Rosselló, J; Segura, J; Suenaga, K \&Verd, J. (2009). Una iniciativa enfocada en la motivación del estudiante en los estudios técnicos:enginy@eps. Escuela
Técnica Superior de Ingeniería del Diseño. 17 Congreso Universitario de Innovación Educativa en las Enseñanzas Técnicas. España: Universidad Politécnica de Valencia. Retrieved from http://www.uib.cat/ant/infsobre/estructura/instituts/ICE/PADU/pags/memories/docs/memories-0809/article_revista_final.pdf

Andrés, C; Menacho, R \& Rey, A. (2010). Influencia que ejerce el acceso y dominio de las TIC en la motivación de los estudiantes en tres cursos de la Escuela de Ciencias Exactas y naturales. XV Congreso Internacional de Tecnología y Educación a distancia. San José, Costa Rica: UNED.

Ayala-Valenzuela \& Torres-Andrade. (2007). Teaching didactics: examples of practices in the Health sector. Universidad Austral de Chile. Medical Superior education. Online version, ISSN 15612902. Valdivia, Chile.

Borges, F. 2005. La frustración del estudiante en línea: causas y acciones preventivas. Digithum. España: UniversitatOberta de Catalunya. Retrieved from http://scholar.google.com/ scholar?q=Motivaci\%C3\%B3n+del+estudiante+virtual\& $\mathrm{hl}=\mathrm{es} \& \mathrm{btnG}=$ Buscar\&l$=$

Padilla-Carmona, M. T. \&J. Gil- Flores. (2010). Evaluando el sistema de evaluación del aprendizaje universitario: análisis documental aplicado al caso de la Universidad de Sevilla. Revista Iberoamericana de Educación 53, 3. Retrieved from http://www.rieoei.org/deloslectores/3574Padilla.pdf

Pujola, J. (2008). La autoevaluación y coevaluación en una enseñanza centrada en la práctica reflexiva. Tesis de Doctorado. España: Universidad de Barcelona, Retrieved from http://estrategiasparaviajar.wikispaces.com/file/view/3. Autoevaluaci\%C3\%B3n.pdf

Quesada, R. (2006). Evaluación del aprendizaje en la educación a distancia en línea. RED. Revista de Educación a Distancia M6. Retrieved from http://redalyc.uaemex.mx/src/inicio/ ArtPdfRed.jsp?iCve $=54709902$

Suárez Riveiro, J. \& Fernández, A. (2011). Evaluación de las estrategias de autorregulación afectivo-motivacional de los estudiantes: Las EEMA-VS. Anales de Psicología, Norteamérica, 27. Retrievedfromhttp://revistas.um.es/analesps/ article/view/122991

Thorpe, M. (2010). Philosophies and theories at the basis of studentcentered educational models. XV International Conference of Technology and distance education. Main conference. San José, Costa Rica.

Vincenzi, A \& Angelis, P. (2008). La evaluación de los aprendizajes de los alumnos. Orientaciones para el diseño de instrumentos de evaluación. Revista de Educación y Desarrollo, 8. Retrieved from http://www.cucs.udg.mx 


\section{APPENDIX 1}

Rubric used to evaluate the forum of the Quality Control course during the third term of 2011.

\begin{tabular}{|c|c|c|c|c|c|}
\hline Items/Value & Excelent (5\%) & Very good $(3,75 \%)$ & $\operatorname{Good}(2,5 \%)$ & Regular (1,25\%) & Unacceptable (0\%) \\
\hline $\begin{array}{l}\text { Participation } \\
\text { (frecuency) }\end{array}$ & 4 participations & 3 participations & 2 participations & One participation & Does not participate \\
\hline $\begin{array}{l}\text { Knowledge } \\
\text { shown }\end{array}$ & $\begin{array}{l}\text { The } 4 \\
\text { participations show } \\
\text { comprehension } \\
\text { and analysis of the } \\
\text { theme }\end{array}$ & $\begin{array}{l}\text { Only } 3 \\
\text { participations } \\
\text { show } \\
\text { comprehension } \\
\text { and analysis of the } \\
\text { theme }\end{array}$ & $\begin{array}{l}\text { Only } 2 \\
\text { participations } \\
\text { show } \\
\text { comprehension } \\
\text { and analysis of the } \\
\text { theme }\end{array}$ & $\begin{array}{l}\text { Only } 1 \\
\text { participation } \\
\text { shows } \\
\text { comprehension } \\
\text { and analysis of the } \\
\text { theme }\end{array}$ & $\begin{array}{l}\text { No participation } \\
\text { shows } \\
\text { comprehension } \\
\text { and analysis of the } \\
\text { theme }\end{array}$ \\
\hline $\begin{array}{l}\text { Interaction with } \\
\text { the group }\end{array}$ & $\begin{array}{l}\text { The student } \\
\text { comments on } \\
\text { at least } 3 \text { other } \\
\text { participations of his/ } \\
\text { her classmates }\end{array}$ & $\begin{array}{l}\text { The student } \\
\text { comments on } \\
\text { at least } 2 \text { other } \\
\text { participations of } \\
\text { his/her classmates }\end{array}$ & $\begin{array}{l}\text { The student } \\
\text { comments } \\
\text { on at least } 1 \\
\text { participation of } \\
\text { his/her classmates }\end{array}$ & $\begin{array}{l}\text { The student } \\
\text { comments on his/ } \\
\text { her classmates' } \\
\text { participations but } \\
\text { in an incorrect way }\end{array}$ & $\begin{array}{l}\text { The student does } \\
\text { not comment } \\
\text { on any of his/ } \\
\text { her classmates' } \\
\text { participations }\end{array}$ \\
\hline $\begin{array}{l}\text { Spelling, } \\
\text { grammar }\end{array}$ & $\begin{array}{l}\text { The spelling and } \\
\text { grammar used } \\
\text { by the student is } \\
\text { correct }\end{array}$ & $\begin{array}{l}\text { The spelling is } \\
\text { correct, grammar } \\
\text { incorrect }\end{array}$ & $\begin{array}{l}\text { Neither grammar } \\
\text { or spelling are } \\
\text { correct }\end{array}$ & - & - \\
\hline
\end{tabular}

\section{APPENDIX 2}

Rubric used to evaluate the case to solve of the Quality Control course during the third term of 2011.

\begin{tabular}{|l|c|}
\hline \multicolumn{1}{|c|}{ Item } & Percentage \\
\hline $\begin{array}{l}\text { Front page (includes personal information, information about the course, about the } \\
\text { term, university) }\end{array}$ & $5 \%$ \\
\hline Introduction (general description of the situation resolved) & $40 \%$ \\
\hline $\begin{array}{l}\text { Analysis and completion of the cause-effect chart (based on the ideal conditions } \\
\text { pointed out in the flowchart }\end{array}$ & $40 \%$ \\
\hline $\begin{array}{l}\text { Identification of the causes that generate the non conformities and elaboration of a } \\
\text { cause-effect diagram }\end{array}$ & \multicolumn{1}{|c|}{$5 \%$} \\
\hline Bibliography (at least four different sources from 2005 to present) & 40 \\
\hline
\end{tabular}




\section{APPENDIX 3}

Rubric used to evaluate the Investigation project of the Quality Control course during the third term of 2011.

\begin{tabular}{|l|c|}
\hline \multicolumn{1}{|c|}{ Items } & Percentage \\
\hline $\begin{array}{l}\text { Front page (includes personal information, } \\
\text { information about the course, about the term, } \\
\text { university) }\end{array}$ & $5 \%$ \\
\hline General index, charts index and figures index & $5 \%$ \\
\hline Abstract & $5 \%$ \\
\hline Introduction & $5 \%$ \\
\hline Problem approach and justification & $15 \%$ \\
\hline $\begin{array}{l}\text { General objective and at least two specific } \\
\text { objectives }\end{array}$ & $5 \%$ \\
\hline Theory (based on bibliographical quotations) & $10 \%$ \\
\hline $\begin{array}{l}\text { Methods (description of each part of the } \\
\text { methodology that lead to the results) }\end{array}$ & $10 \%$ \\
\hline $\begin{array}{l}\text { Results and discussion (charts, figures and } \\
\text { discussion with a thorough analysis) }\end{array}$ & $15 \%$ \\
\hline Conclusions (from results not theory) & $5 \%$ \\
\hline $\begin{array}{l}\text { Recommendations (at least two, justify them and } \\
\text { point out the methodology used to get to the } \\
\text { recommendation) }\end{array}$ & $15 \%$ \\
\hline Bibliography & $5 \%$ \\
\hline
\end{tabular}




\section{APPENDIX 4}

Survey sent to the Students to measure their motivation and perception of the Quality Control course during the third term of 2011.

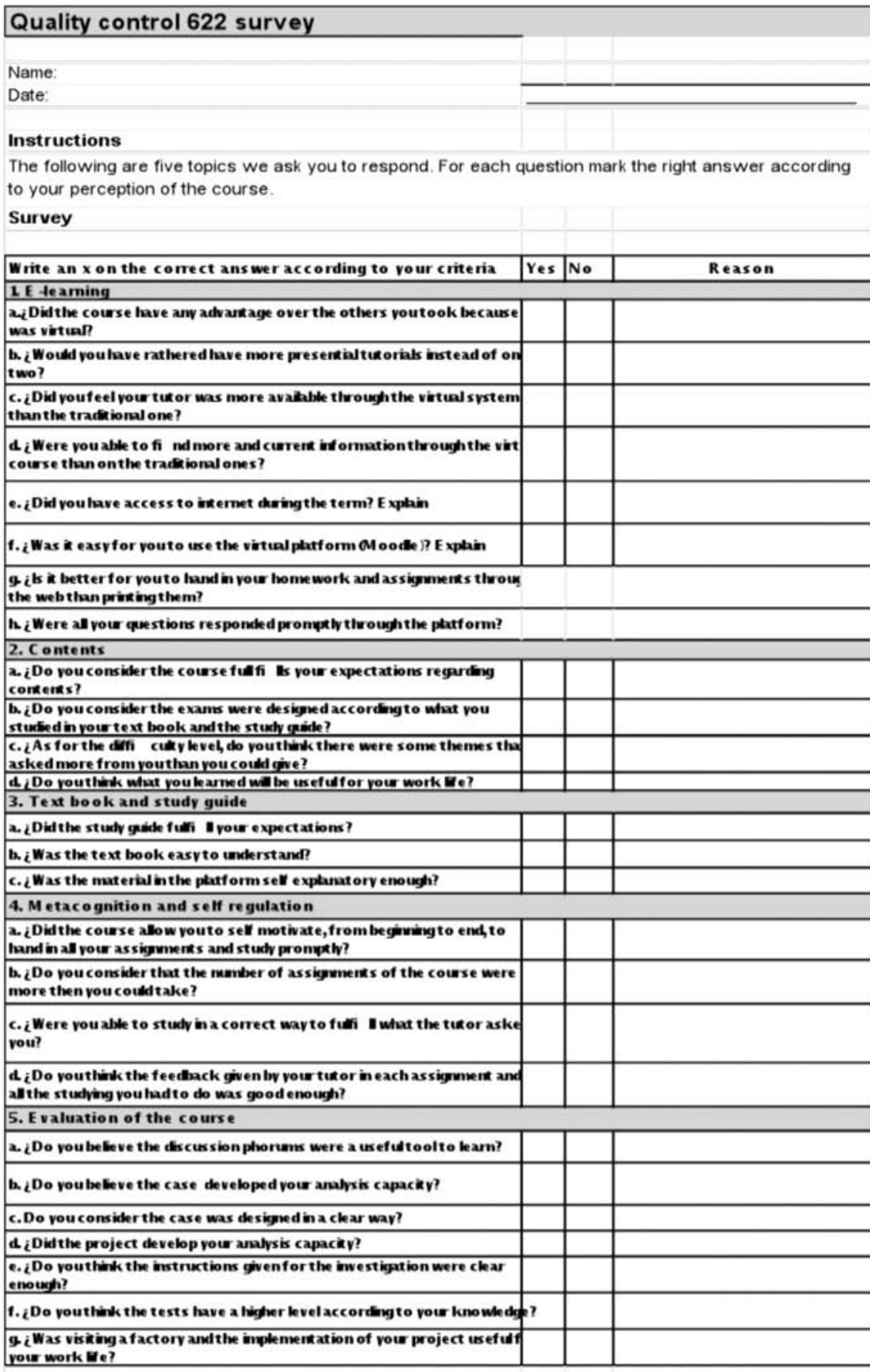

Thank you very much for your help! 


\section{APPENDIX 5}

Self evaluation of the students at the end of the Quality Control course during the third term of 2011.

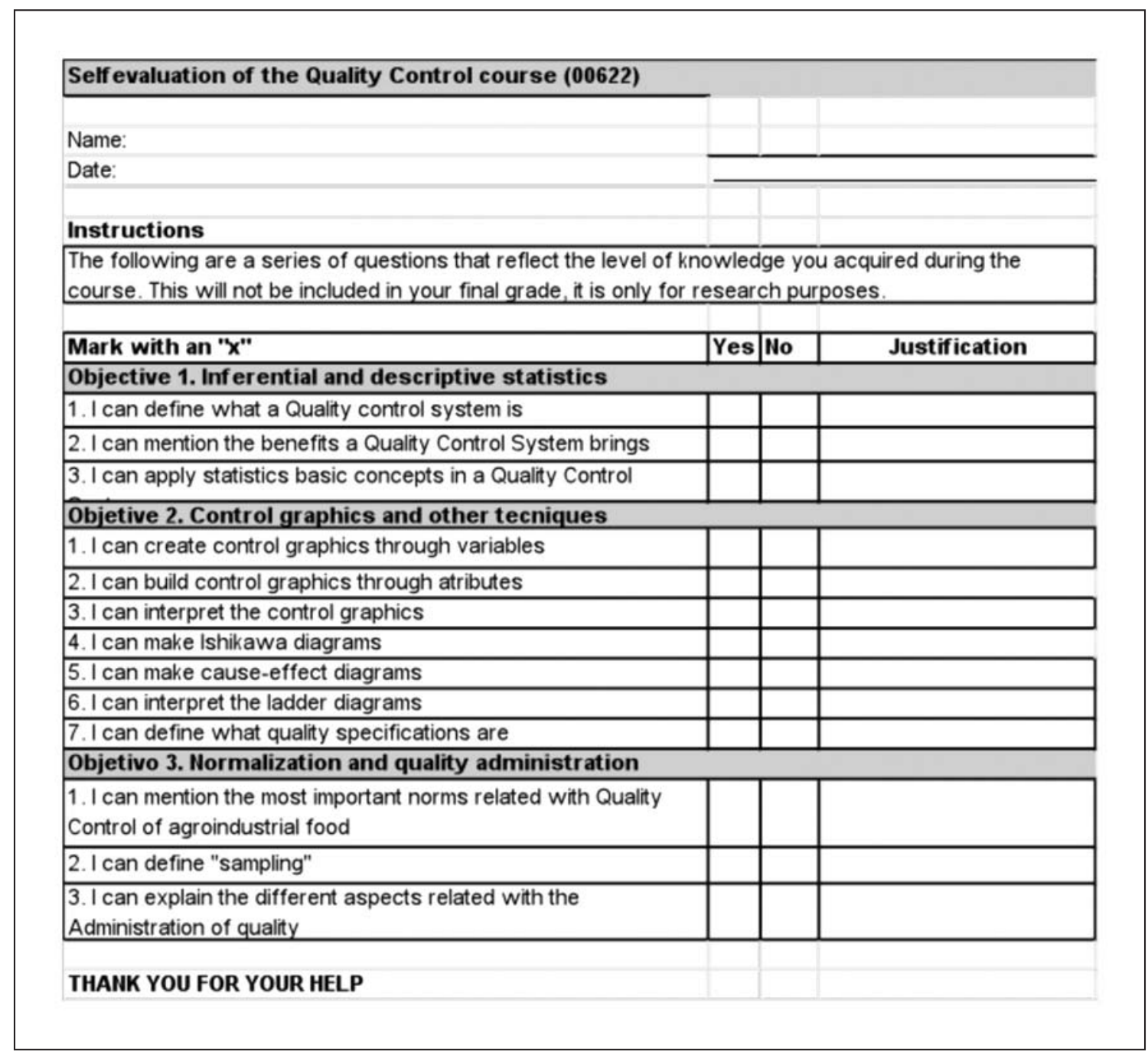


